\title{
Ciglitazone, an agonist of peroxisome proliferator-activated receptor $\gamma$, exerts potentiated cytostatic/cytotoxic effects against tumor cells when combined with lovastatin
}

\author{
PIOTR MRÓWKA ${ }^{1,2}$, ELIZA GLODKOWSKA ${ }^{1}$, DOMINIKA NOWIS ${ }^{1}$, MAGDALENA LEGAT $^{1,3}$, \\ TADEUSZ ISSAT ${ }^{1}$, MARCIN MAKOWSKI ${ }^{1}$, ANGELIKA SZOKALSKA ${ }^{1}$, SYLWIA JANOWSKA ${ }^{1}$, \\ TOMASZ STOKLOSA ${ }^{1}$, MAREK JAKÓBISIAK ${ }^{1}$ and JAKUB GOLAB ${ }^{1}$ \\ ${ }^{1}$ Department of Immunology, Center of Biostructure Research, The Medical University of Warsaw, Banacha 1a, \\ 02-097 Warsaw; ${ }^{2}$ Department of Biophysics and Human Physiology, The Medical University of Warsaw, \\ Chalubinskiego 5, 02-004 Warsaw; ${ }^{3}$ Department of Laboratory Diagnostics and Clinical Immunology, \\ The Medical University of Warsaw, Marszalkowska 24, 00-576 Warsaw, Poland
}

Received July 16, 2007; Accepted September 20, 2007

\begin{abstract}
Thiazolidinediones are ligands of PPAR- $\gamma$, a member of the nuclear receptor family. These drugs have shown promising pre-clinical activity in tumor models but clinical studies failed to confirm their beneficial effect. We have studied the in vitro antitumor effects of a combination of ciglitazone, a thiazolidinedione drug, and lovastatin, an inhibitor of 3-hydroxy-3-methylglutaryl-coenzyme A reductase. We observed a marked synergism in several different tumor cell lines resulting from both inhibition of cell proliferation and induction of apoptosis. These results strongly suggest that combining PPAR $-\gamma$ agonists with statins can produce significant antitumor effects.
\end{abstract}

\section{Introduction}

Peroxisome proliferator-activated receptor $\gamma(\operatorname{PPAR}-\gamma)$ is a member of a nuclear hormone receptor family and is a ligandactivated transcription factor (1). Long-chain polyunsaturated fatty acids, arachidonic acid metabolites such as 15-deoxy$\Delta^{12,14}$-prostaglandin $\mathbf{J}_{2}\left(15-\mathrm{PGJ}_{2}\right)$ and fatty acid-derived

Correspondence to: Dr Jakub Golab, Department of Immunology, Center of Biostructure Research, The Medical University of Warsaw, Banacha 1a, F building, 02-097 Warsaw, Poland

E-mail: jgolab@ib.amwaw.edu.pl

Abbreviations: CDK, cyclin dependent kinase; CI, combination index; HMG-CoA, 3-hydroxy-3-methylglutaryl-coenzyme A; PPAR- $\gamma$, peroxisome proliferator-activated receptor $\gamma$; RXR, retinoid $\mathrm{X}$ receptor

Key words: statins, thiazolidinediones, peroxisome proliferatoractivated receptor $\gamma, 3$-hydroxy-3-methylglutaryl-coenzyme A components are natural ligands of PPAR- $\gamma$. On ligand binding PPAR- $\gamma$ forms a heteromeric complex with retinoid $\mathrm{X}$ receptor (RXR) and binds to specific recognition sequences, the peroxisome proliferator response elements, located within promoters of target genes that regulate proliferation, terminal differentiation, apoptosis and angiogenesis (2).

Synthetic ligands of PPAR- $\gamma$ receptors include anti-diabetic thiazolidinedione drugs such as troglitazone, rosiglitazone, pioglitazone and ciglitazone as well as some non-steroidal anti-inflammatory drugs such as indomethacin, ibuprofen or fenoprofen (3). Although adipocytes express the highest levels of PPAR- $\gamma$, the receptor is also expressed in many other tissues and cell types and in many types of cancer. Thiazolidinediones have shown promising cytostatic/cytotoxic effects against cancer cells in vitro and in vivo (1,3-5). Although the mechanisms of these effects have not been completely elucidated several lines of evidence indicate that thiazolidinediones can increase the levels of cyclin-dependent kinase inhibitors such as $\mathrm{p} 21^{\text {Wafl }}$ and $\mathrm{p} 27^{\mathrm{Kip} 1}$, thereby halting cell cycle progression (6-8). Additionally, thiazolidinediones have been shown to induce apoptosis of tumor cells, associated with caspase-3 activation and decreased expression of anti-apoptotic proteins BCL-2 and BCL- $\mathrm{X}_{\mathrm{L}}(9,10)$. Also DNA microarray analysis of gene expression profiles in thiazolidinedione-treated tumor cells revealed PPAR- $\gamma$ targets associated with growth regulatory pathways (11).

Statins are inhibitors of 3-hydroxy-3-methylglutarylcoenzyme A (HMG-CoA) reductase, a rate-limiting enzyme in a metabolic pathway of cholesterol biosynthesis $(12,13)$. By inhibiting synthesis of mevalonic acid, an essential precursor of isoprenoid compounds, dolichol, and ubiquinone as well as farnesyl and geranylgeranyl groups required for posttranslational modification of many proteins including Ras/ Rho superfamily members, statins exert pleiotropic biologic effects. Although statins are commonly used in the management of hypercholesterolemia and cardiovascular diseases, recent preclinical observations indicate that these drugs can also exert direct antiproliferative and pro-apoptotic effects against 
tumor cells (12-14). Accordingly, several clinical studies were undertaken to investigate both chemopreventive and direct antitumor effects of statins. Although some studies indicated that statins can decrease the risk of development of several types of cancer $(15,16)$, recent meta-analyses do not show unequivocal beneficial effects of these drugs as far as cancer incidence is concerned (17-19). Similarly, clinical trials did not show any significant antitumor effects of statins (20-22). It seems that statins are unlikely to become antitumor drugs. Nonetheless, they are among the most frequently prescribed therapeutics used by elderly patients for the management of cardiovascular diseases. Because of their age these patients are also at an increased risk of developing cancer. Therefore, any combination treatments with statins characterized by potentiated antitumor effects are being studied. We have studied the cytostatic effects of statins used together with ciglitazone, a PPAR $-\gamma$ agonist.

\section{Materials and methods}

Tumors. Panc 02, murine pancreatic carcinoma cells were kindly obtained from Carsten Ziske (Rheinische FriedrichWilhelms-Universität, Bonn, Germany). Murine mammary tumor EMT6, murine colon adenocarcinoma C-26, human mammary adenocarcinoma MDA-MB-361, human pancreatic cancer MIA PaCa-2 and human osteosarcoma MG-63 cell lines were obtained from ATCC. Cells were cultured in RPMI-1640 (Sigma-Aldrich, St. Louis, MO, USA) or Dulbecco's modified Eagle's medium (DMEM; SigmaAldrich), supplemented with $10 \%$ heat-inactivated fetal calf serum (FCS), and antibiotics (all from Gibco BRL, Paisley, $\mathrm{UK})$, hereafter referred to as culture medium. Cells were maintained in a humidified $5 \% \mathrm{CO}_{2}$ atmosphere at $37^{\circ} \mathrm{C}$.

Drugs and reagents. Ciglitazone was purchased from A.G. Scientific Inc., San Diego, CA, USA. It was diluted in dimethyl sulfoxide (DMSO; Sigma-Aldrich) to a final concentration of $50 \mathrm{mM}$. Lovastatin was obtained from Merck \& Co., Inc., Whitehouse Station, NJ, USA and was stored as a $10-\mathrm{mM}$ stock. It was obtained in the inactive lactone form that was converted to the active form as described (23). Stock solutions were aliquoted and stored at $-20^{\circ} \mathrm{C}$.

Cytostatic/cytotoxic assay. The cytostatic and/or cytotoxic effects of combination treatment were measured using crystal violet staining as described (24). Cells were dispensed into a 96-well flat-bottomed microtiter plate (Nunc, Rochester, NY, USA) at a concentration of $3 \times 10^{3}$ cells $/ 100 \mu 1 /$ well and allowed to attach overnight. Then, the cells were treated for $48 \mathrm{~h}$ with the different ciglitazone and lovastatin concentrations alone or in combinations. The dose of DMSO equal to the highest concentration of DMSO used as a dissolvent of therapeutics did not exert any biological effects. After $48 \mathrm{~h}$ of incubation the medium was removed, and the wells were washed with PBS and stained with $0.5 \%$ crystal violet in $30 \%$ ethanol for $10 \mathrm{~min}$ at room temperature. The plates were washed four times with tap water. The cells were lysed in $1 \%$ SDS solution, and dye uptake was measured at $595 \mathrm{~nm}$ using an ELISA reader (BioRad 680XR microplate reader). Results are expressed as a mean compared to control $\pm \mathrm{SD}$. The relative viability was calculated as follows: relative viability $=[$ (experimental absorbance - background absorbance)/(untreated control absorbance - background absorbance)] x100\%.

Morphological observations. The morphology of Panc 02 cells was examined after $48 \mathrm{~h}$ of treatment directly on the plates by phase contrast microscopy (Nikon Eclipse TE2000-U connected to Nikon Digital Sight DS-U1 camera). For the examination of nuclear morphology, cells were stained with DNA fluorescent dye Hoechst 33342 (Sigma-Aldrich). The stock solution was dissolved 1:1 in ethanol and then in PBS without $\mathrm{Ca}^{2+}, \mathrm{Mg}^{2+}$ to a final concentration of $0.1 \mathrm{mg} / \mathrm{ml}$. Of the prepared solution, $300 \mu \mathrm{l}$ was added to $3 \mathrm{ml}$ of culture medium in each plate. Cells were incubated with dye at a temperature of $37^{\circ} \mathrm{C}$ for $15 \mathrm{~min}$. Medium containing Hoechst 33342 solution was removed and PBS was added. Morphology of nuclei was examined by fluorescent microscopy (Nikon Eclipse TE2000-U connected to Nikon Digital Sight DS-U1 camera).

Western blotting. For Western blotting studies, Panc 02 cells were cultured with ciglitazone at a concentration of $25 \mu \mathrm{M}$ and lovastatin at concentrations of 0.25 and $0.5 \mu \mathrm{M}$. After $48 \mathrm{~h}$ of culture, the cells were collected and lysed as described previously (25). Protein concentrations were measured with the use of Bradford's method (BioRad, Rockville, NY, USA). Equal amounts of proteins were separated on $12.5 \%$ SDSpolyacrylamide gel, transferred onto nitrocellulose membranes, blocked with TBST [Tris-buffered saline ( $\mathrm{pH} 7.4), 0.05 \%$ Tween-20] with 5\% nonfat milk and 5\% fetal bovine serum. The primary antibodies were applied overnight at $4^{\circ} \mathrm{C}$ at a dilution of 1:1000. Antibodies recognizing the following antigens were used: p21 ${ }^{\text {Wafl }}$ (Santa Cruz Biotechnology Inc., Santa Cruz, CA, USA), p27 Kip1 (Cell Signaling Technology Inc., Beverly, MA, USA), and PARP (Santa Cruz Biotechnology Inc.). Anti- $\alpha$-tubulin specific antibody (Santa Cruz Biotechnology Inc.) served as a protein loading control. After extensive washing with TBST, the membranes were incubated for $45 \mathrm{~min}$ in corresponding horseradish peroxidase-coupled secondary antibodies (ImmunoPure antibody goat anti-mouse and donkey anti-rabbit; Pierce, Rockford, IL, USA). The chemiluminescent reaction was developed using West Pico (Pierce) reagent. Densitometric analysis of scanned membranes was performed using ImageQuant 5.2 software (Amersham Bioscience, Piscataway, NJ, USA). The relative amount of the target protein was calculated by the following formula: density of the target band/density of the control band ( $\alpha$-tubulin or uncleaved PARP), and shown as percentage of control.

Flow cytometry. For the analysis of cell cycle Panc 02 cells were plated in Petri dishes (Nunc) and after the cell attachment drugs were added. After $48 \mathrm{~h}$ of incubation cells were collected, washed with PBS and fixed in ice-cold $70 \%$ ethanol in $50 \mathrm{mM}$ $\mathrm{PBS}, \mathrm{pH} 7.3$, and kept at $-20^{\circ} \mathrm{C}$ until analyzed (up to 5 days later, not less than 1 day). Before the staining, cells were spun and washed twice with PBS. The cells were resuspended in $5 \mu \mathrm{g} / \mathrm{ml}$ propidium iodide (PI) in PBS with RNAse free from DNAse $(1 \mu \mathrm{g} / \mathrm{ml})$ and were incubated for $45 \mathrm{~min}$ at $37^{\circ} \mathrm{C}$. Cells were analyzed by FACS (Becton Dickinson, Franklin Lakes, NJ, USA). 
Panc 02

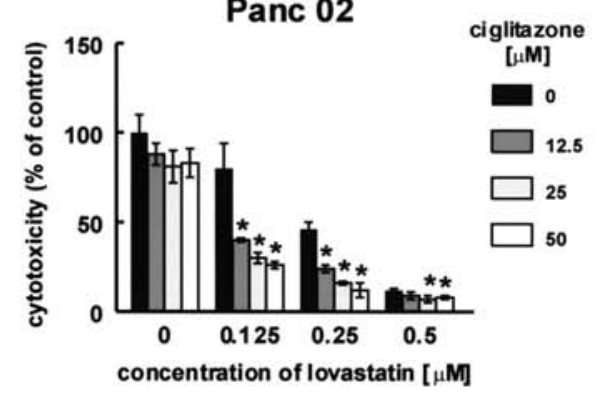

C-26

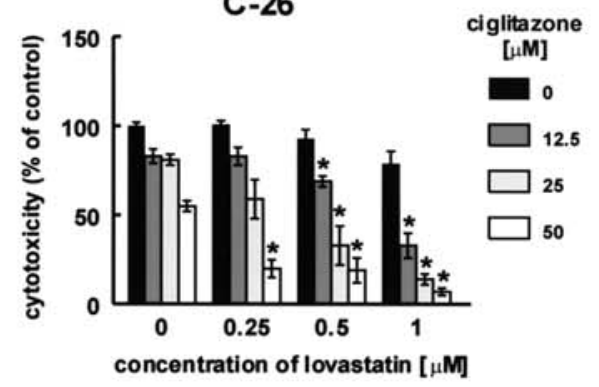

MLA PaCa-2
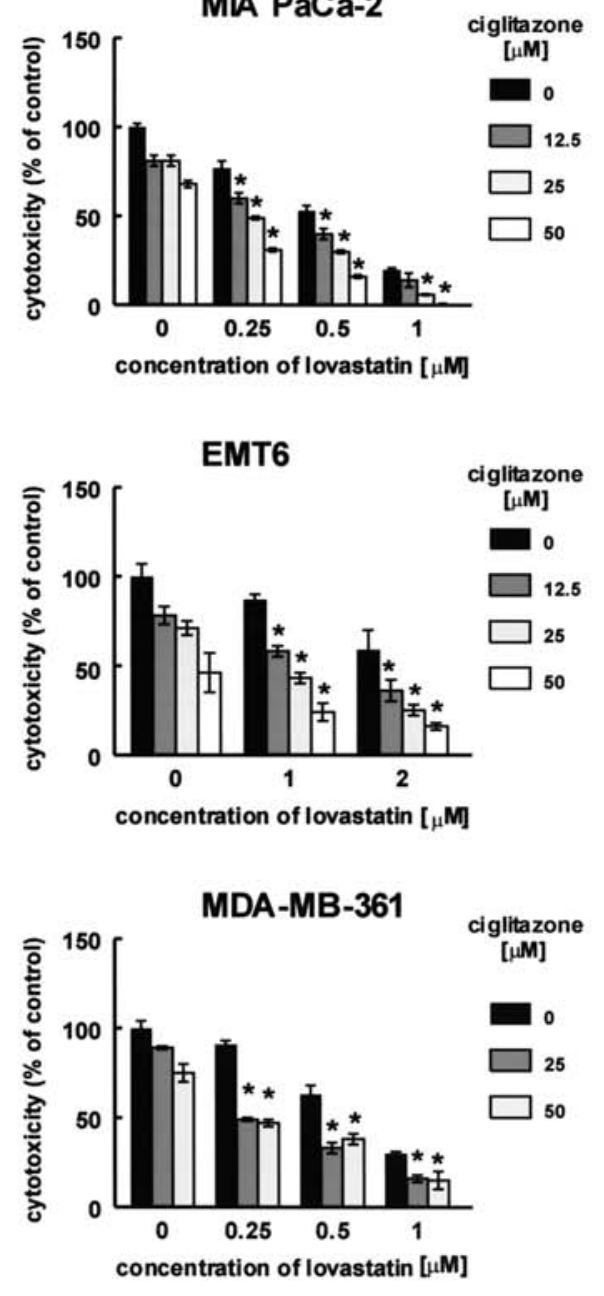
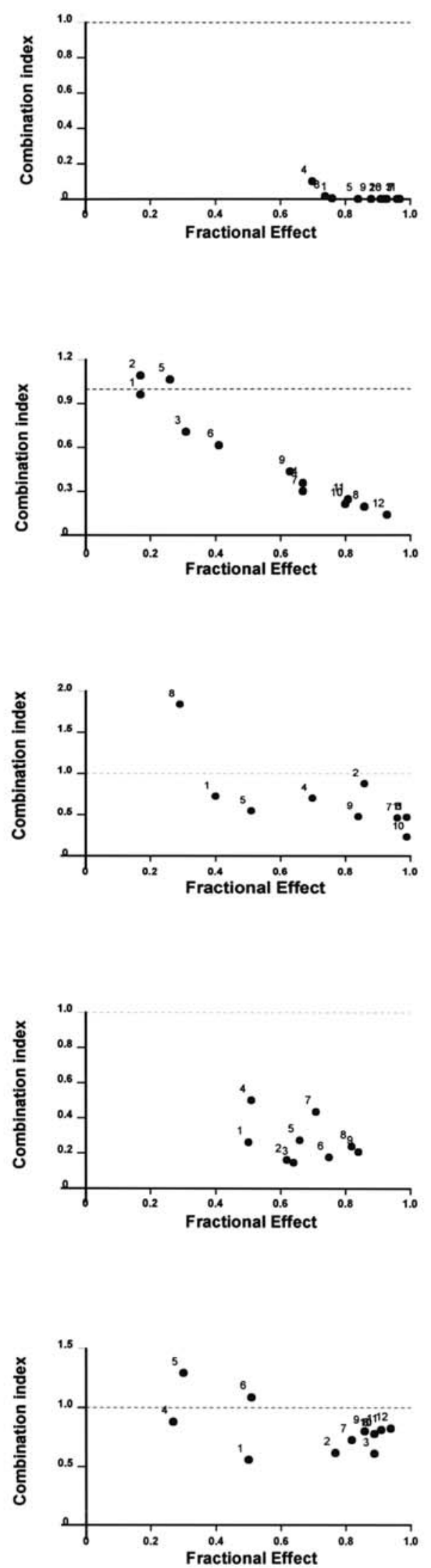

Figure 1. Cytostatic/cytotoxic effects of ciglitazone and/or lovastatin against tumor cells. Tumor cells of pancreatic (Panc 02, MIA PaCa-2), breast (MDAMB-361, EMT6) and colorectal (C-26) origin were dispensed into a 96-well flat-bottomed microtiter plate at a concentration of 5-10x10 3 cells/100 $\mu 1 /$ well. Cells were incubated with dilutions of ciglitazone and/or lovastatin or a control DMSO-containing medium. After $48 \mathrm{~h}$ the cytostatic/cytotoxic effects were measured using crystal violet staining and are expressed as mean survival (as compared with controls) \pm S.D. Next to the graphs showing cytostatic/cytotoxic effects there are results of the Chow and Talalay analyses of the combination indices (CI) presented here as a function of inhibition of cell growth in cells exposed to ciglitazone and lovastatin for $48 \mathrm{~h}$. Each numbered dot corresponds to a particular combination calculated by CalcuSyn software. The straight line at $\mathrm{CI}=1$ represents the additive effects of both drugs. ${ }^{*} \mathrm{P}<0.05$ (Student's t-test) as compared with controls and single agent-treated cells. 

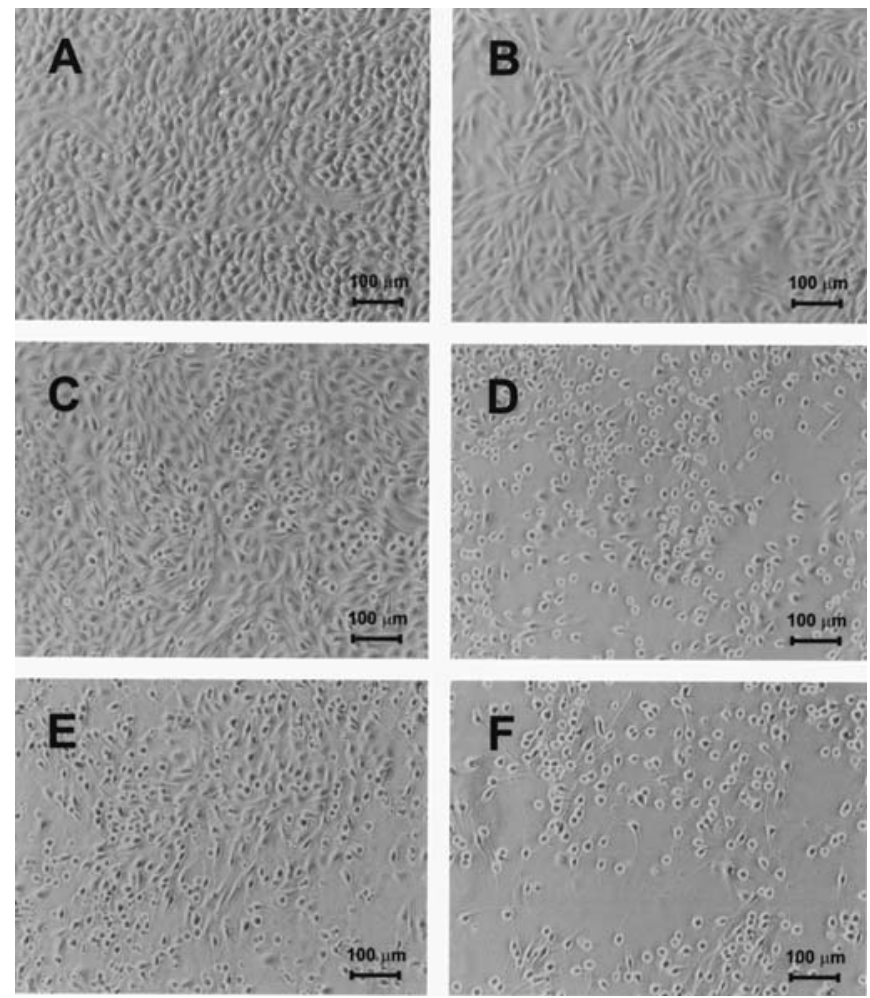

Figure 2. The morphology of Panc 02 cells incubated with ciglitazone and/or lovastatin. Panc 02 cells were grown in Petri dishes for $24 \mathrm{~h}$ before 48 -h incubation with compounds. Cells were treated with DMSO (controls) (A), ciglitazone $(25 \mu \mathrm{M})(\mathrm{B})$ or lovastatin at concentrations of $0.25 \mu \mathrm{M}(\mathrm{C})$ and $0.5 \mu \mathrm{M}(\mathrm{E})$. The morphology of cells incubated with ciglitazone and lovastatin at $0.25 \mu \mathrm{M}$ is shown in $\mathrm{D}$, and the morphology of cells incubated with ciglitazone and lovastatin at $0.5 \mu \mathrm{M}$ is shown in F. After $48 \mathrm{~h}$ of incubation with the drugs the cells were observed using phase contrast microscopy.

Statistical analyses. Data were calculated using Microsoft ${ }^{\mathrm{TM}}$ Excel 2000. Statistical significance was determined using Student's t-test. Values of $\mathrm{p}<0.05$ were considered as statistically significant. The nature of the interaction observed between ciglitazone and lovastatin was analysed using the CalcuSyn software (Biosoft, Cambridge, UK) which uses the combination index (CI) method of Chou and Talalay (26), based on multiple drug effect equation. The advantage of this method is the automatic construction of a fraction affected-CI table, graph, and calculation of dose reduction indices by the software. CIs of $<1$ indicate greater than additive effects (synergism; the smaller the value, the greater the degree of synergy), CIs equal to 1 indicate additivity, and CIs $>1$ indicate antagonism. The dose reduction index defines the extent of drug dose reduction possible in combination for a given degree of effect as compared with the dose of each drug alone (26).

\section{Results}

Both murine and human tumour cell lines of various origin, i.e. murine (Panc 02) and human (MIA PaCa-2) pancreatic cancer cells, murine (C-26) colon carcinoma cells, murine (EMT6) breast carcinoma cells, and human (MDA-MB-361) mammary adenocarcinoma cells were incubated with ciglitazone, lovastatin or a combination of both drugs for $48 \mathrm{~h}$. The results of quantitative cytotoxic/cytostatic effects measured
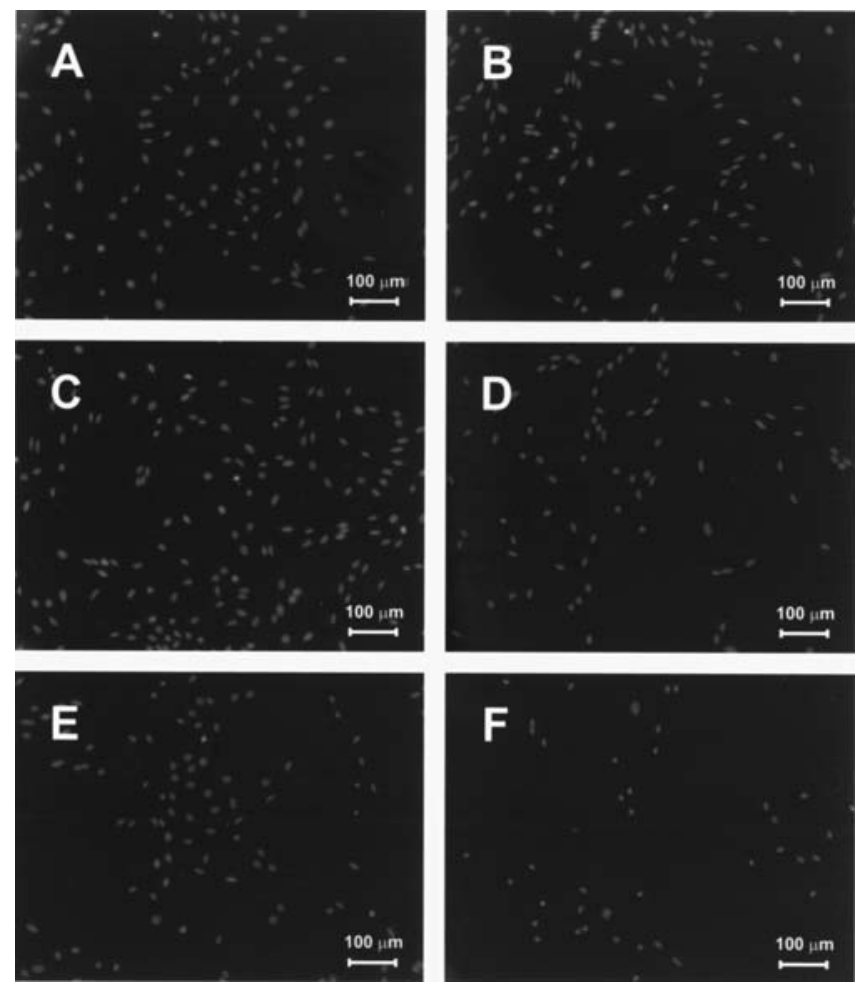

Figure 3. The nuclear morphology of Panc 02 cells incubated with ciglitazone and/or lovastatin. Panc 02 cells were grown in Petri dishes for $24 \mathrm{~h}$ before 48-h incubation with compounds. Cells were treated with DMSO (controls) (A), ciglitazone $(25 \mu \mathrm{M})(\mathrm{B})$ or lovastatin at concentrations of $0.25 \mu \mathrm{M}(\mathrm{C})$ and $0.5 \mu \mathrm{M}(\mathrm{E})$. The morphology of cells incubated with ciglitazone and lovastatin at $0.25 \mu \mathrm{M}$ is shown in $\mathrm{D}$, and the morphology of cells incubated with ciglitazone and lovastatin at $0.5 \mu \mathrm{M}$ is shown in $\mathrm{F}$. After $48 \mathrm{~h}$ of treatment cells were stained with fluorescent dye Hoechst 33342 and examined using fluorescent microscopy.

with a crystal violet staining assay are shown in Fig. 1. In all investigated cell lines the combination exerted potentiated cytostatic/cytotoxic effects as compared with single agenttreated cells over a wide range of concentrations studied. The resulting data were elaborated with a dedicated software CalcuSyn to verify potential synergistic interactions between the investigated agents using Chow and Talalay calculation. In this mathematical model, synergism can be defined when the combination index $(\mathrm{CI})$ is $<1.0$ (when $\mathrm{CI}$ is $<0.5$ the synergism is defined as very strong). We have found that the combination of ciglitazone and lovastatin was highly synergistic when both drugs were used against Panc 02, C-26 and EMT6 cells. A synergistic interaction was also noted for MIA PaCa-2 and MDA-MB-361 cells with only a few drug combinations showing highly synergistic effects (Fig. 1).

In addition to cellular viability, the shrinkage morphology of Panc 02 cells treated with the combination of ciglitazone $(25 \mu \mathrm{M})$ and lovastatin (used at both 0.25 and $0.5 \mu \mathrm{M}$ concentrations) was markedly different from that of control cells or cells incubated with single agent only (Fig. 2). Analysis of nuclear morphology by Hoechst staining (Fig. 3) revealed that combination of $0.5 \mu \mathrm{M}$ lovastatin and $25 \mu \mathrm{M}$ ciglitazone induced an apoptosis-like shrinkage of nuclei and chromatin condensation (Fig. 3F). This phenomenon was not observed in control cells (Fig. 3A), cells treated with ciglitazone (Fig. 3B) or lovastatin alone (Fig. 3C and E) nor in cells 

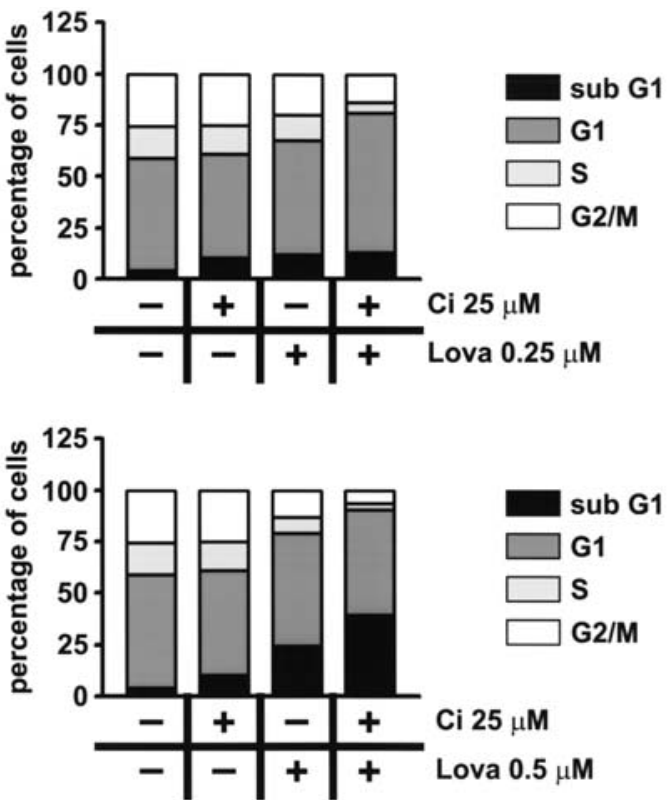

Figure 4. Cell cycle distribution of Panc 02 cells incubated with ciglitazone and/or lovastatin. Panc 02 cells were grown in Petri dishes for $24 \mathrm{~h}$ before 48-h incubation with compounds. Cells were incubated with ciglitazone at a $25-\mu \mathrm{M}$ concentration alone and/or lovastatin at $0.25-\mu \mathrm{M}$ and $0.5-\mu \mathrm{M}$ concentrations. Cell cycle analysis was performed by flow cytometric analysis using ethanol-fixed, propidium iodide-stained cells.

incubated with ciglitazone and a lower $(0.25 \mu \mathrm{M})$ lovastatin concentration (Fig. 3D). These results suggest that there might be different mechanisms of cytostatic/cytotoxic effects with the combinations of drugs depending on lovastatin concentration. At lower lovastatin doses cytostatic effects dominate while at higher concentrations apoptotic cell death might occur.

To verify this hypothesis we performed FACS analysis of cell cycle distribution of Panc 02 cells using propidium iodide staining as well as Western blot analysis to gain insight into the expression of cell cycle- and apoptosis-associated proteins. The results shown in Fig. 4 corroborate previous findings. For the lower lovastatin concentration $(0.25 \mu \mathrm{M})$ addition of ciglitazone $(25 \mu \mathrm{M})$ increased the percentage of cells arrested in G1 phase of the cell cycle from up to $48 \%$ in single agent-treated cells to $61 \%$ in combination-treated cells. SubG1 phase consists of cells with abnormally low content of DNA which is mainly caused by DNA degradation during the apoptosis process and thus might represent apoptosis induction. Lovastatin at a $0.5-\mu \mathrm{M}$ concentration increased the percentage of cells in subG1 phase from $3 \%$ in controls to $21 \%$. Co-incubation of Panc 02 cells with $0.5 \mu \mathrm{M}$ lovastatin and ciglitazone at a concentration of $25 \mu \mathrm{M}$ that only insignificantly increased the number of cells in subG1 (from $3 \%$ to $7 \%$ ) resulted in accumulation of cells with a decreased DNA content in $>37 \%$ of cells.

To elucidate these observations further we assessed the expression of $\mathrm{p} 21^{\text {Waf1 }}$ and $\mathrm{p} 27^{\mathrm{Kip} 1}$, the inhibitors of cyclindependent kinases. A 48-h incubation of Panc 02 with ciglitazone $(25 \mu \mathrm{M})$ and lovastatin $(0.5$ and $0.25 \mu \mathrm{M})$ alone did not influence $\mathrm{p} 27^{\mathrm{Kip} 1}$ level, as determined by Western blotting (Fig. 5A). The combinations of both agents resulted in 2.8 -fold up-regulation of $\mathrm{p} 27^{\mathrm{Kip} 1}$ when lovastatin was used at a $0.25-\mu \mathrm{M}$
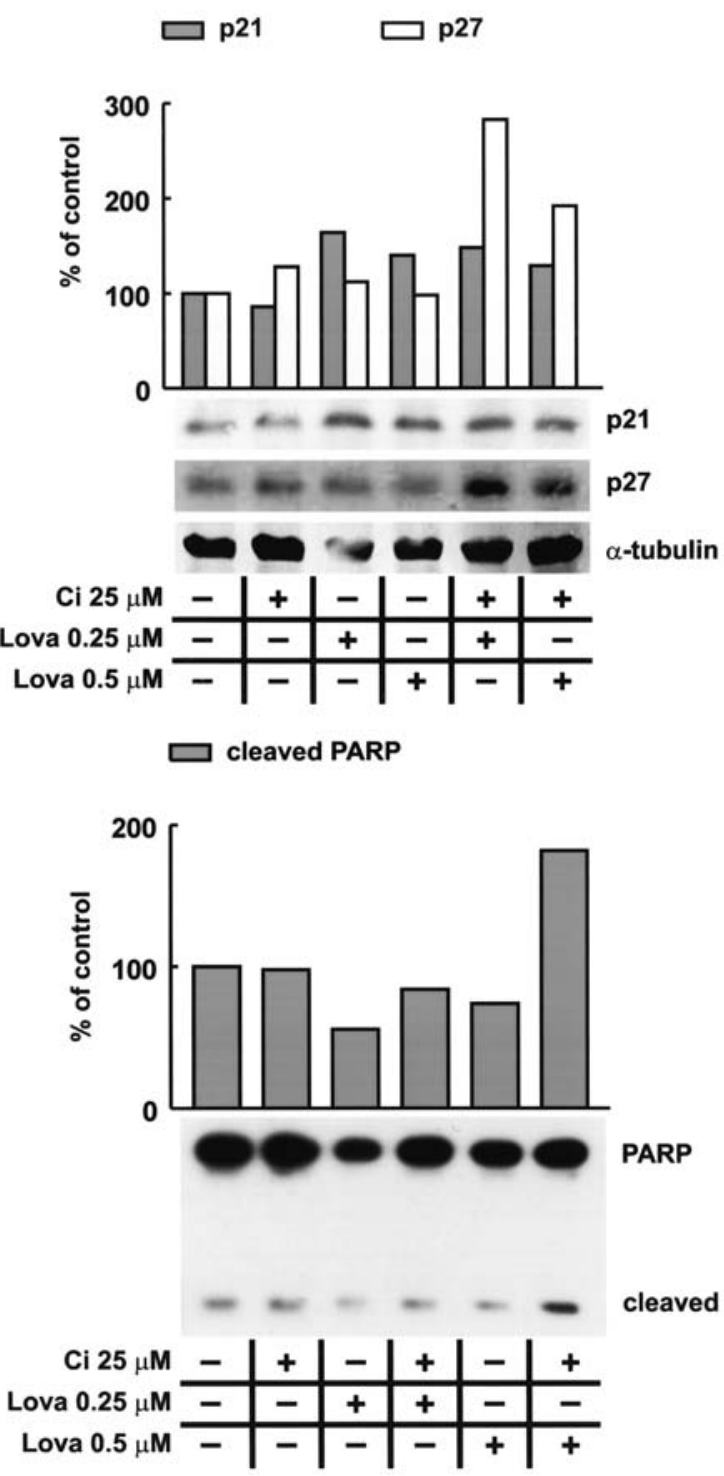

cleaved PARP

Figure 5. Western blot analysis of $\mathrm{p} 21^{\text {Waf1 }}$, p $27^{\text {Kipl }}$ and PARP in Panc 02 cells incubated with ciglitazone and/or lovastatin. Panc 02 cells were incubated with ciglitazone at a $25-\mu \mathrm{M}$ concentration alone and/or lovastatin at $0.25-\mu \mathrm{M}$ and $0.5-\mu \mathrm{M}$ concentrations. After $48 \mathrm{~h}$ of incubation cells were harvested and the prepared cell lysates were subjected to Western blot analysis: $50 \mu \mathrm{g}$ of protein extracts were separated during electrophoresis. Blots were sequentially probed (after stripping) with different antibodies. The appropriate bands were scanned and quantified with ImageQuant 5.2 software. The relative amount of target proteins was calculated by the following formula: density of the target band/density of the control band ( $\alpha$-tubulin or uncleaved PARP), and shown as percentage of controls.

concentration and almost a 2-fold increase when lovastatin was used at a higher concentration of $0.5 \mu \mathrm{M}$. p $21^{\text {Waf1 }}$ levels increased in groups treated with both doses of lovastatin but in cells co-treated with ciglitazone the level remained unaffected in comparison to cells incubated with agents in monotherapy.

To investigate whether the DNA loss observed in flow cytometry analysis was related to apoptosis induction we examined PARP cleavage in Panc 02 cells co-incubated with lovastatin $(0.5 \mu \mathrm{M})$ and ciglitazone $(25 \mu \mathrm{M})$. As shown in Fig. 5B the ratio of cleaved $85-\mathrm{kDa}$ form of PARP to uncleaved $116-\mathrm{kDa}$ form was 1.8 -fold higher for the combination of $0.5 \mu \mathrm{M}$ lovastatin and $25 \mu \mathrm{M}$ ciglitazone. The ratio was not increased in any other incubation group. 


\section{Discussion}

It has recently been demonstrated that lovastatin significantly potentiates antitumor effects of troglitazone against lung, prostate, pancreas, and uterine cancer cells as well as against glioblastoma cells in vitro (27). Here we have extended these studies by showing that lovastatin can also effectively potentiate cytostatic/cytotoxic effects of ciglitazone, another thiazolidinedione against mammary, colon, and pancreas carcinomas and, to a lesser degree, against osteosarcoma cells (data not shown). Interestingly, we did not observe any cytostatic/cytotoxic interaction between lovastatin and pioglitazone, other PPAR- $\gamma$ agonist (data not shown). Thiazolidinediones have recently been demonstrated to exert potent cytostatic/cytotoxic effects in vitro and in vivo in different tumor models (3-5). These drugs were shown to induce accumulation of cyclin-dependent kinase inhibitors such as p1 $8^{\mathrm{INK} 4 \mathrm{C}}, \mathrm{p} 21^{\text {Waf1 }}$ and $\mathrm{p} 27^{\mathrm{Kip} 1}(7,8,28,29)$. PPAR- $\gamma$ agonists were also able to decrease expression of cyclin D1 and inhibit the activity of CDK2, CDK4 and CDK6 (30). Moreover, several recent observations indicate that activation of PPAR- $\gamma$ is associated with inhibition of phosphatidylinositol 3'-kinase (PI3K)/Akt activity, an effect that might be directly related to thiazolidinedione-induced stimulation of PTEN expression (31-33). Similarly, statins were shown to interfere with cell cycle progression by affecting the expression levels and activity of CDKs and their inhibitors (34-36). We observed that although ciglitazone at a dose of $25 \mu \mathrm{M}$ did not affect expression levels of $\mathrm{p} 21^{\text {Waf } 1}$ and $\mathrm{p} 27^{\mathrm{Kip} 1}$ it significantly increased expression of $\mathrm{p} 27^{\mathrm{Kip} 1}$ when combined with lovastatin at $0.25 \mu \mathrm{M}$. At a higher lovastatin concentration $(0.5 \mu \mathrm{M})$ pancreatic tumor cells revealed morphologic and biochemical markers of apoptosis. The mechanisms responsible for these observations are perhaps multifactorial. Both statins and PPAR $-\gamma$ agonists were previously shown to exert pleiotropic effects in cells. For example, statins by inhibiting posttranslational prenylation of numerous proteins such as Ras/Rho family members can influence important signal transduction pathways affecting gene expression (37). Being activators of transcription factors PPAR- $\gamma$ agonists naturally increase expression of numerous target genes relevant to differentiation (3). Both statins and PPAR- $\gamma$ agonists were also shown to inhibit the activity of proteasome thereby post-translationally regulating the levels of a number of proteins $(38,39)$. Therefore, because of such pleiotropic effects exerted by these drugs the detailed molecular mechanisms of the observed interaction will be difficult to pinpoint.

Both statins and thiazolidinediones have also been demonstrated to exert additional antitumor effects, such as inhibition of angiogenesis and tumor cell invasiveness, that should encourage further studies of this combination (40-43). It should also be emphasized that both statins and thiazolidinediones have already been used in humans for many years, showing not only clinical efficacy but also safety. Moreover, the combination of simvastatin and pioglitazone has recently been shown to produce potentiated anti-inflammatory effects in non-diabetic patients with cardiovascular disease and elevated high-sensitivity C-reactive protein (hs-CRP) levels (44). The combined regimen was both effective and safe. As chronic inflammation is inadvertently associated with tumor progression these studies provide additional rationale for testing the combination of statins and thiazolidinediones in preclinical tumor models before launching clinical trials.

\section{Acknowledgements}

This study was supported by grant 1M19/WB1 from the Medical University of Warsaw. We would like to thank Anna Czerepinska and Elzbieta Gutowska for their excellent technical assistance.

\section{References}

1. Theocharis S, Margeli A, Vielh P and Kouraklis G: Peroxisome proliferator-activated receptor-gamma ligands as cell-cycle modulators. Cancer Treat Rev 30: 545-554, 2004.

2. Sertzing PS, Seifert M, Tilgen W and Reichrath J: Present concepts and future outlook: function of peroxisome proliferatoractivated receptors (PPARs) for pathogenesis, progression, and therapy of cancer. J Cell Physiol 212: 1-12, 2007.

3. Wang T, Xu J, Yu X, Yang R and Han ZC: Peroxisome proliferator-activated receptor gamma in malignant diseases. Crit Rev Oncol Hematol 58: 1-14, 2006.

4. Koeffler HP: Peroxisome proliferator-activated receptor gamma and cancers. Clin Cancer Res 9: 1-9, 2003.

5. Grommes C, Landreth GE and Heneka MT: Antineoplastic effects of peroxisome proliferator-activated receptor $\gamma$ agonists. Lancet Oncol 5: 419-429, 2004.

6. Elnemr A, Ohta T, Iwata K, et al: PPARgamma ligand (thiazolidinedione) induces growth arrest and differentiation markers of human pancreatic cancer cells. Int J Oncol 17: 1157-1164, 2000.

7. Radhakrishnan SK and Gartel AL: The PPAR-gamma agonist pioglitazone post-transcriptionally induces p 21 in PC3 prostate cancer but not in other cell lines. Cell Cycle 4: 582-584, 2005.

8. Motomura W, Okumura T, Takahashi N, Obara T and Kohgo Y: Activation of peroxisome proliferator-activated receptor gamma by troglitazone inhibits cell growth through the increase of p27KiP1 in human. Pancreatic carcinoma cells. Cancer Res 60: 5558-5564, 2000.

9. Elstner E, Muller C, Koshizuka K, et al: Ligands for peroxisome proliferator-activated receptor gamma and retinoic acid receptor inhibit growth and induce apoptosis of human breast cancer cells in vitro and in BNX mice. Proc Natl Acad Sci USA 95: 8806-8811, 1998.

10. Chattopadhyay N, Singh DP, Heese O, et al: Expression of peroxisome proliferator-activated receptors (PPARs) in human astrocytic cells: PPARgamma agonists as inducers of apoptosis. J Neurosci Res 61: 67-74, 2000.

11. Vignati S, Albertini V, Rinaldi A, et al: Cellular and molecular consequences of peroxisome proliferator-activated receptorgamma activation in ovarian cancer cells. Neoplasia 8: 851-861, 2006 .

12. Katz MS: Therapy insight: Potential of statins for cancer chemoprevention and therapy. Nat Clin Pract Oncol 2: 82-89, 2005.

13. Jakobisiak M and Golab J: Potential antitumor effects of statins (Review). Int J Oncol 23: 1055-1069, 2003.

14. Fritz G: HMG-CoA reductase inhibitors (statins) as anticancer drugs (Review). Int J Oncol 27: 1401-1409, 2005.

15. Poynter JN, Gruber SB, Higgins PD, et al: Statins and the risk of colorectal cancer. N Engl J Med 352: 2184-2192, 2005.

16. Khurana V, Bejjanki HR, Caldito G and Owens MW: Statins reduce the risk of lung cancer in humans: a large case-control study of US veterans. Chest 131: 1282-1288, 2007.

17. Bonovas S, Filioussi K, Tsavaris N and Sitaras NM: Use of statins and breast cancer: a meta-analysis of seven randomized clinical trials and nine observational studies. J Clin Oncol 23: 8606-8612, 2005

18. Browning DR and Martin RM: Statins and risk of cancer: a systematic review and metaanalysis. Int J Cancer 120: 833-843, 2007.

19. Dale KM, Coleman CI, Henyan NN, Kluger J and White CM: Statins and cancer risk: a meta-analysis. JAMA 295: 74-80, 2006. 
20. Holstein SA, Knapp HR, Clamon GH, Murry DJ and Hohl RJ: Pharmacodynamic effects of high dose lovastatin in subjects with advanced malignancies. Cancer Chemother Pharmacol 57: 155-164, 2006.

21. Kawata S, Yamasaki E, Nagase T, et al: Effect of pravastatin on survival in patients with advanced hepatocellular carcinoma. A randomized controlled trial. Br J Cancer 84: 886-891, 2001.

22. Thibault A, Samid D, Tompkins AC, et al: Phase I study of lovastatin, an inhibitor of the mevalonate pathway, in patients with cancer. Clin Cancer Res 2: 483-491, 1996.

23. Feleszko W, Zagozdzon R, Golab J and Jakobisiak M: Potentiated antitumour effects of cisplatin and lovastatin against MmB16 melanoma in mice. Eur J Cancer 34: 406-411, 1998.

24. Issat T, Nowis D, Legat M, et al: Potentiated antitumor effects of the combination treatment with statins and pamidronate in vitro and in vivo. Int J Oncol 30: 1413-1425, 2007.

25. Nowis D, Legat M, Grzela T, et al: Heme oxygenase- 1 protects tumor cells against photodynamic therapy-mediated cytotoxicity. Oncogene 25: 3365-3374, 2006.

26. Chou TC and Talalay P: Quantitative analysis of dose-effect relationships: the combined effects of multiple drugs or enzyme inhibitors. Adv Enzyme Regul 22: 27-55, 1984.

27. Yao CJ, Lai GM, Chan CF, Cheng AL, Yang YY and Chuang SE: Dramatic synergistic anticancer effect of clinically achievable doses of lovastatin and troglitazone. Int J Cancer 118: 773-779, 2006.

28. Motomura W, Takahashi N, Nagamine M, et al: Growth arrest by troglitazone is mediated by $\mathrm{p} 27 \mathrm{Kip} 1$ accumulation, which results from dual inhibition of proteasome activity and Skp2 expression in human hepatocellular carcinoma cells. Int J Cancer 108: 41-46, 2004.

29. Koga H, Sakisaka S, Harada M, et al: Involvement of p21(WAF1/Cip1), p27(Kip1), and p18(INK4c) in troglitazoneinduced cell-cycle arrest in human hepatoma cell lines. Hepatology 33: 1087-1097, 2001.

30. Yin F, Wakino S, Liu Z, et al: Troglitazone inhibits growth of MCF-7 breast carcinoma cells by targeting G1 cell cycle regulators. Biochem Biophys Res Commun 286: 916-922, 2001.

31. Shao J, Sheng H and DuBois RN: Peroxisome proliferatoractivated receptors modulate K-Ras-mediated transformation of intestinal epithelial cells. Cancer Res 62: 3282-3288, 2002.

32. Patel L, Pass I, Coxon P, Downes CP, Smith SA and Macphee CH: Tumor suppressor and anti-inflammatory actions of PPARgamma agonists are mediated via upregulation of PTEN. Curr Biol 11: 764-768, 2001.
33. Lee SY, Hur GY, Jung KH, et al: PPAR-gamma agonist increases gefitinib's antitumor activity through PTEN expression. Lung Cancer 51: 297-301, 2006.

34. Giermasz A, Makowski M, Kozlowska E, et al: Potentiating antitumor effects of a combination therapy with lovastatin and butyrate in the Lewis lung carcinoma model in mice. Int J Cancer 97: 746-750, 2002.

35. Laufs U, Marra D, Node K and Liao JK: 3-Hydroxy-3methylglutaryl-CoA reductase inhibitors attenuate vascular smooth muscle proliferation by preventing rho GTPase-induced down-regulation of p27(Kip1). J Biol Chem 274: 21926-21931, 1999.

36. Ukomadu $\mathrm{C}$ and Dutta A: Inhibition of cdk2 activating phosphorylation by mevastatin. J Biol Chem 278: 4840-4846, 2003.

37. Konstantinopoulos PA, Karamouzis MV and Papavassiliou AG: Post-translational modifications and regulation of the RAS superfamily of GTPases as anticancer targets. Nat Rev Drug Discov 6: 541-555, 2007

38. Takeuchi S, Okumura T, Motomura W, Nagamine M, Takahashi $\mathrm{N}$ and Kohgo Y: Troglitazone induces G1 arrest by p27(Kip1) induction that is mediated by inhibition of proteasome in human gastric cancer cells. Jpn J Cancer Res 93: 774-782, 2002.

39. Wojcik C, Bury M, Stoklosa T, et al: Lovastatin and simvastatin are modulators of the proteasome. Int J Biochem Cell Biol 32: 957-965, 2000

40. Kusama T, Mukai M, Iwasaki T, et al: 3-hydroxy-3methylglutaryl-coenzyme a reductase inhibitors reduce human pancreatic cancer cell invasion and metastasis. Gastroenterology 122: 308-317, 2002.

41. Panigrahy D, Singer S, Shen LQ, et al: PPARgamma ligands inhibit primary tumor growth and metastasis by inhibiting angiogenesis. J Clin Invest 110: 923-932, 2002.

42. Feleszko W, Lasek W, Golab J and Jakobisiak M: Synergistic antitumor activity of tumor necrosis factor-alpha and lovastatin against MmB16 melanoma in mice. Neoplasma 42: 69-74, 1995.

43. Matar P, Rozados VR, Binda MM, Roggero EA, Bonfil RD and Scharovsky OG: Inhibitory effect of Lovastatin on spontaneous metastases derived from a rat lymphoma. Clin Exp Metastasis 17: 19-25, 1999.

44. Hanefeld M, Marx N, Pfutzner A, et al: Anti-inflammatory effects of pioglitazone and/or simvastatin in high cardiovascular risk patients with elevated high sensitivity C-reactive protein: the PIOSTAT study. J Am Coll Cardiol 49: 290-297, 2007. 